\title{
DYEING OF TEXTILES WITH NATURAL DYES
}

\author{
Sonja Jordeva ${ }^{1 *}$, Marija Kertakova', Silvana Zhezhova', \\ Sashka Golomeova Longurova ${ }^{1}$, Kiro Mojsov' $^{1}$
}

\author{
'University "Goce Delchev", Shtip, Faculty of Technology,Shtip, \\ Republic of North Macedonia \\ *e-mail: sonja.jordeva@ugd.edu.mk
}

Professional paper

UDC: 677.026:667.7

doi: $10.5937 /$ tekstind2004012J

\begin{abstract}
In recent years there has been a great interest in the application of natural dyes in dyeing textiles due to their biodegradability and high compatibility with the environment. According to the experts, there is a great potential for using natural dyes to the extent that in some areas they can very easily replace synthetic ones. This paper reports the studies available on the characterization, classification and analysis of natural dyes; extraction of dyes from onion's outer shell and effects of different mordants and mordanting methods on the color shade. From an environmental point of view, replacing synthetic dyes with natural ones is not only a strategy to reduce risk and pollutants, but also an opportunity for new markets and jobs.
\end{abstract}

Keywords: natural dyes, mordants, extraction, onion's outer shell.

\section{BOJENJE TEKSTILA PRIRODNIM BOJAMA}

Apstract: Poslednjih godina postoji veliko interesovanje za primenu prirodnih boja u bojenju tekstila zbog njihove biorazgradivosti i visoke kompatibilnosti sa okolinom. Prema stručnjacima, postoji veliki potencijal za upotrebu prirodnih boja do te mere da u nekim oblastima mogu vrlo lako zameniti sintetičke. Ovaj rad izveštava o dostupnim studijama o karakterizaciji, klasifikaciji i analizi prirodnih boja; ekstrakciji boja iz spoljne ljuske luka i efektima različitih sredstava za fiksiranje boja (močila) kao i metodama njihovog nanošenja na nijansu boje. Sa ekološkog stanovišta, zamena sintetičkih boja prirodnim nije samo strategija za smanjenje rizika i zagađujućih materija, već i prilika za razvoj novih tržišta i radnih mesta.

Ključne reči: prirodne boje, fiksatori boje, ekstrakcija, spoljašnja ljuska luka.

\section{INTRODUCTION}

Textile materials (natural and synthetic) used to be coloured for value addition, look and desire of the customers. The textiles were dyed with dyes of natural sources until the synthetic dyes were invented and commercialized. Dyes of natural sources were replaced by synthetic dyes because the new dyes could be mass produced with consistent shades of color. Natural dyes are known for their use in colouring of food substrate, leather as well as natural fibres like wool, silk and cotton as major areas of application. The Society of Dyers \& Colourist's Colour Index (3rd edition) defines natural colouring matters as 'the natural dyes and pigments comprise of all colours obtained from animal and vegetable matter with no or very little chemical treatments. The term natural dye covers all the dyes derived from the natural sources like plants, animal and minerals $[1,2]$.

The global consumption of textiles is estimated at around 30 million tonnes. The dyeing of this huge amount of textiles needs around 700,000 tonnes of dyes which causes release of a waste into the environment. Such a huge amount of required textiles materials cannot be dyed with natural dyes alone. Hence, the use of eco-safe synthetic dyes is also essential. But a certain portion of coloured textiles can always be supplemented and managed by eco-safe natural dyes [3].

The amount of natural dyes present in natural products are very less. Specific technique to remove 
dye from their original source are needed. There are some methods which are suitable for extraction of natural dyes from their source materials. The different extraction methods are as follows: aqueous extraction, acid and alkali extraction, ultrasonic microwave extraction, by fermentation and solvent extraction. The choice of solvent depends on their chemical composition. Water, ethanol, methanol, ether, etc. are most often used as solvents. Natural dyes are mostly non-substantive and must be applied on textiles by the help of mordants, usually a metallic salt, having an affinity for both the colouring matter and the fibre. During the dyeing of the textile material with natural dyes, the dye molecules form complexes with the metal ions with which the material is processed before dyeing. Depending on the metal salts (mordants) used, different shades of color (hues) are obtained [1,4,5].

Natural dyes are mostly used for dyeing of the textiles from natural fibers to enhance their eco-friendly characteristics. Apart from indigo, other natural dyes are usually not used for printing directly. As well as synthetic dyes, natural dyes can be used to dye textiles at all stages such as fiber, yarn, or fabric [6]. Natural dyes are biodegradable and do not cause any health hazards and hence they can be easily used without much environment concerns. Recently, there has been revival of the growing interest on the application of natural dyes to overcome the environmental damage caused by synthetic dyes. However, all-natural dyes are not ecofriendly. There may be presence of heavy metals or some other form of toxicity in natural dye. So, the natural dyes also need to be tested for toxicity before their use [3].

The prevention of microbial attack on textiles has become increasingly important to consumers and textiles producers. Therefore, interests in antimicrobial fabric finishing have steadily increased over the last few years. Application of natural antimicrobial agents on textiles dates back to antiquity, when the ancient Egyptians used spices and herbs to preserve mummy wraps. Natural antimicrobials were used to inhibit the growth of bacteria and mould in the fabric. Curcumin had been used in the Eastern and Western part of the world as a vegetable dye for coloring silk and cotton and also as an essential part of many medicines to treat certain diseases. Many properties that have been attributed to curcumin in pharmacological studies have demonstrated that curcumin used in traditional medicine possess antiinflammatory, antifungal, antitumor activities, and also as a cancer chemopreventive agent [7].
Although natural dyes can not be an alternative to synthetics, their application is increasingly being explored in the new scientific literature. The opinions of environmentalists and manufacturers of synthetic days are opposed. The opinion of environmentalists is to discard everything that is "chemical" and "synthetic" and replace it with "bio" and "eco" products. On the other hand, manufacturers of synthetic dyes believe that natural dyes can not be an alternative due to the lack of natural resources, inability to dye synthetic fibers, low color fastness, higher costs of dyeing and production, etc. [4].

While some experts are focused on the many difficulties in applying natural dyes to textile dyes, others emphasize the advantages of technology based on sustainable sources [8].

\section{CLASSIFICATION OF NATURAL DYES}

The natural dyes can be classified in different ways such as based on origin/source type, type of hue, chemical structure and colour components (Figure 1). According to the origine natural dyes can be with: vegetable, animal or mineral origin. Most natural dyes are extracted from different parts of plants and trees $[1,5]$. About 500 vegetable origin dyes, colouring matter derived from root, leaf, bark, trunk or fruit of plants [1]. Representatives of the vegetable dyes are: Turmeric (Curcuma longa), Onion's outer shell, (Allium cepa), Indigo (Indigofera tinctoria), Madder or Manjistha or Rubia (Rubia tinctorum), Tea waste (Camellia sinensis), Pomegranate rind (Punica granatum), Banana leaf dyes, Eucalyptus leaves $[5,9$, 10 , 11]. Typical representative of dyes from animal origine is Cochineal (Dactylopius coccus). Some kinds of mineral ores, red clay and ball clay can yield light colours along with mineral salts. But colour composition is not constant and depends on source. Table 1 shows the vegetable natural dyes from different parts of plants.

Natural dyes have wide application in the dying of most of the natural fibres, e.g. cotton, linen, wool and silk fibre, and to some extant for nylon and polyester synthetic fibre. However, the major issues for natural dyed textiles are reproducibility of shade, non availability of well-defined standard procedure for application and poor lasting performance of shade under water and light exposure. By chemical constitution natural dyes can be divided in: Indigoid class (blue dye), Anthraquinone class (red shade), Alpha naphthoquinone, Flavones (yellow shade), Carotenoids, Dihydropyrans (dark black shade), Anthocyanidins [5]. 


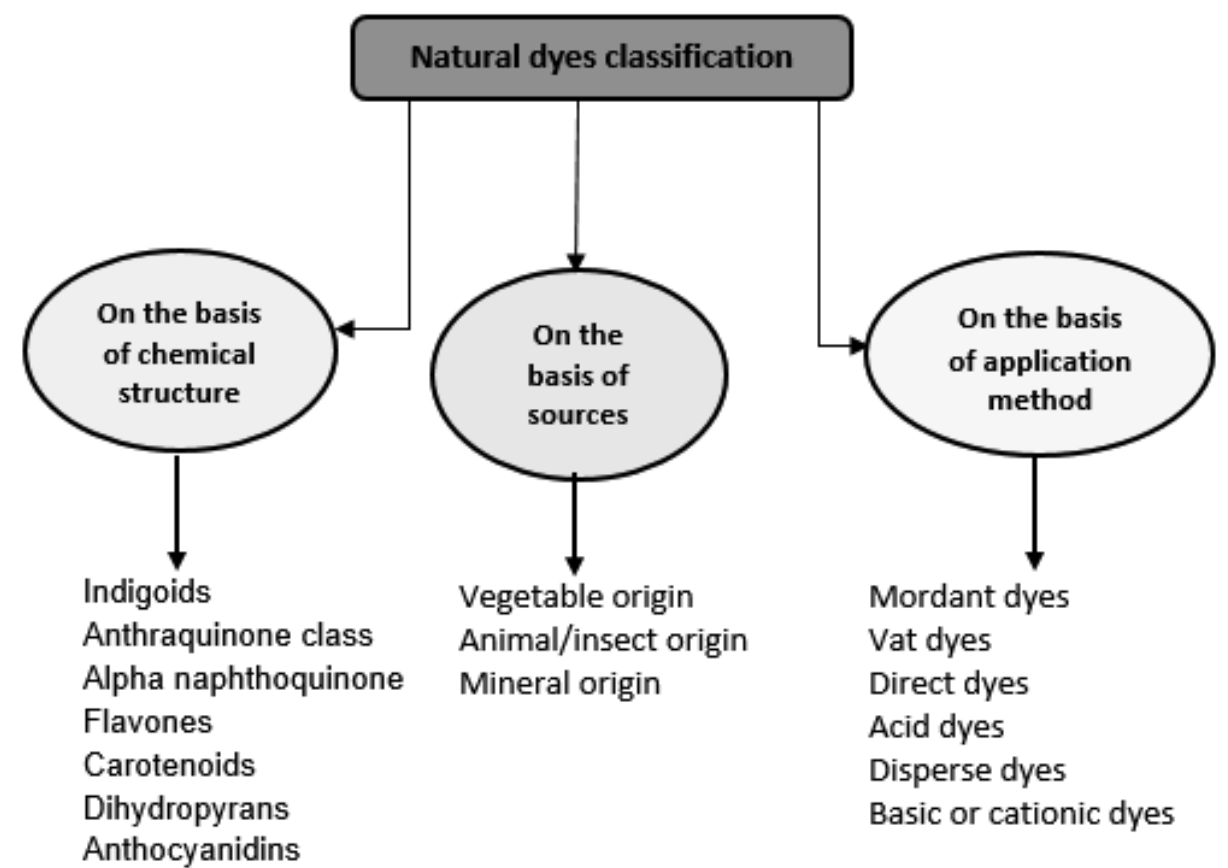

Figure 1: Natural dyes classification

Table 1: Vegetable natural dyes from different parts of plants, [1]

\begin{tabular}{|c|c|}
\hline Part of the plants & Dyestuffs \\
\hline Root & Turmeric, Madder (Manjistha) Onions, Beet-root \\
\hline Branches & Purple bark, Red Sandalwood \\
\hline Leaf & Indigo, Henna, Eucaliptus, Tea, Cardamon, Lemon Grass \\
\hline Fruits/Seeds & Pomergnate rind, Beetle nut \\
\hline
\end{tabular}

On the basis of application method natyral dyes can be: $[1,6]$.

- Mordant dyes are dyestuffs which require a mordant in their application as they

have no affinity for the fiber being dyed.

- Vat dyes are water insoluble dyes which are first converted to their water-soluble form. The true colour is produced only on oxidation followed, by treatment with a hot soap solution, e.g., indigo.

- Direct dyes are the natural dyes which are water soluble and have a long and planar molecular structure and presence of conjugated (single and double bonds) bonds. Turmeric and Pomegranate rind are the representatives of the direct natural dyes.

- Acid dyes are applied from an acidic medium, at $\mathrm{pH}$ of 4.5-5.5.

- Disperse dyes have a relatively low molecular mass, low solubility and no strong solubilizing groups. Disperse dyes can be applied on to hydrophobic synthetic fibre from neutral to mildly acidic $\mathrm{pH}$. They can also be applied to silk and wool.

- Basic or cationic dyes on ionization give coloured cations and form an electrovalent bond with the $-\mathrm{COOH}$ group of wool and silk. These dyes are applied from neutral to mildly acidic $\mathrm{pH}=4-5$. These dyes have poor light fastness, e.g., berberine.

The classification of natural dyes can be done according to the hue of the colour [5].

- Red: Colour index has 32 red natural dyes. The representatives are Maddar, Manjistha, and Cochineal.

- Blue: There are four natural blue dyes. Some prominent colours are indigo, Kumbh and flowers of Japanese Tsuykusa. Natural indigo blue is known from very ancient time to dye cotton and wool.

- Yellow: There are 28 yellow natural dyes available which are used in dyeing of wool, silk and cotton. Prominent examples are Barberry, Tesu flowers, Kamala, Turmeric and Marigold. 
- Green: Plants that yield green natural colour are very rare; they are made by mixing yellow and blue primary colours. Woad and Indigo produce green colour.

- Black and brown: There are six black natural dyes. Cutch is used to produce brown shade; for getting black shade lac, carbon and caramel are used.

Different regions of the world had their own natural dyeing traditions utilizing the natural resources available in that region. The most used natural dyes in our region are: walnut bark, peel and leaves, ash bark and leaf, linden leaf, peach, quince, apples, St. John's wort, onion's outer shell etc. From the mentioned plants different colors are obtained: red, yellow, blue, green, orange, gray, black, etc.

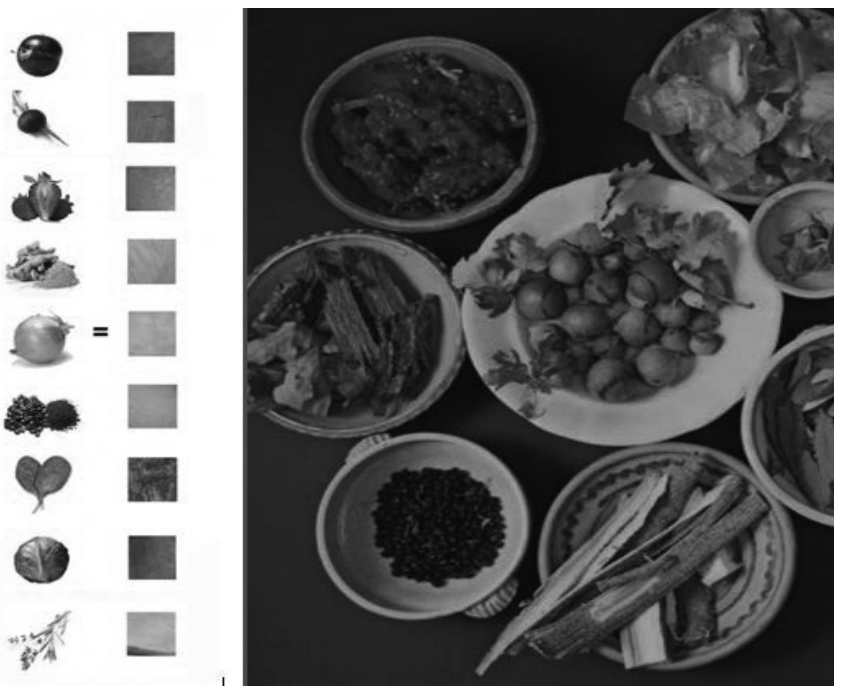

Figure 2: Sources of natural dyes [12]

Leaf, bark, root, and walnut shells, black thorn, and young oak are commonly used to dye wool in black color. In the dyeing process it is necessary to add mordant. The root of the plant Rubia tinctorium $\mathrm{L}$ gives a red color. The plant produces anthraquinone pigments, one of which is alizarin (1.2 dihydroxy anthraquinone), and has been used to dye textiles since 2000 BC. These pigments are persistent on heat and light. They are used for dyeing cotton and woolen materials. Depending on the mordant, different shades are obtained: with iron salts a purple color is obtained; chromium salts give brownish-red; with the salts of aluminum and calcium a very good red color is obtained. The root of wild apple (Malus silvestris), saffron (Cartamus tinctorius), white mulberry leaf, onion's outer shell (Allium cepa) and others give yellow color [4].
For successful commercial use of natural dyes appropriate scientific techniques need to be established by scientific studies on dyeing methods, dyeing kinetics and compatibility of selective natural dyes in order to obtain hues with acceptable colour fastness behavior and reproducible colour yield [13].

\section{EXTRACTION PROCESS OF COLOUR COMPONENT FROM NATURAL DYES, MORDANTS AND MORDANTING METHODS}

The colour component present in various sources like flowers, roots, bark, animal sources, mineral sources etc. needs to be extracted so that it can be applied on the textile. Most vegetable dyes are extracted by pulverizing, grinding or soaking and boiling the herbs in water [2]. Extraction is basically the rupture of cell wall of the plant to evolve the colorant in media. The conventional methods involve soaking, stirring, heating, reflux etc. [14].

The extraction efficiency of colourant components present in natural sources depends on the media type (aqueous/ organic solvent or acids/ alkali), $\mathrm{pH}$ of the media and conditions of extraction, such as temperature and time.

Dayal and Dobhal, [15] extracted colourants from the leaves of Eucalyptus hybrid, seeds of Cassia tora and Grewia optiva by using aqueous medium under varying condition. These dyes can be used for dyeing silk, wool, cotton and jute fabrics by using alum, copper sulphate, ferrous sulphate, potassium dichromate and stannous chloride as mordants.

Teli and Paul [16] have done efforts to extract natural dye from the coffee seed for its application on cotton and silk. The results obtained showed that coffee-seed extract develops a range of shades with good fastness properties on cotton and silk.

Pan et al. [17] investigated dyeing of juta fabric with the extracts from the green leaves of deodara, jackfruit and eucalyptus. The leaves were cut into small pieces and soaked in soft water (1000 g leaves in $1000 \mathrm{ml}$ of water). Leavs were boiled for $4 \mathrm{~h}$. The replenishment of evaporated water was carried out during boiling. The dye constituents present in the natural colorants were transferred to the aqueous solution during boiling. Aqueous extracts of deodara leaf, jackfruit leaf and eucalyptus leaf yield light brown to light mustard shades with good wash fastness on bleached jute fabrics.

Many researchers $[18,19,20]$ have been worked on extraction of colorants component from mariegold in aqueous medium. Sarkar et al worked with 
Marigold, Butterfly pea, China rose and Balsam. Use of acid dye bath choice of acid showed a definite improvement in the substantivity. Result showed good substantivity on flax fiber. According to Tsatsaroni and Eleftheriadis [20], aqueous extraction of saffron yields a yellow dye with medium wash fastness on wool and poor wash fastness on cotton. In contrast, the dye gives medium light fastness on cotton and poor light fastness on wool.

Natural dyes are categorized as substantive or adjective dyes. Substantive dyes have good fastness properties and need no medium for dye application on fabric, whereas adjective dyes acquire medium for their application on fabrics. Most of the natural dyes demand medium to create link between the fiber and the dye (Figure 3), [14]. These media are chemicals that create affinity between dye and fabric called "mordants".

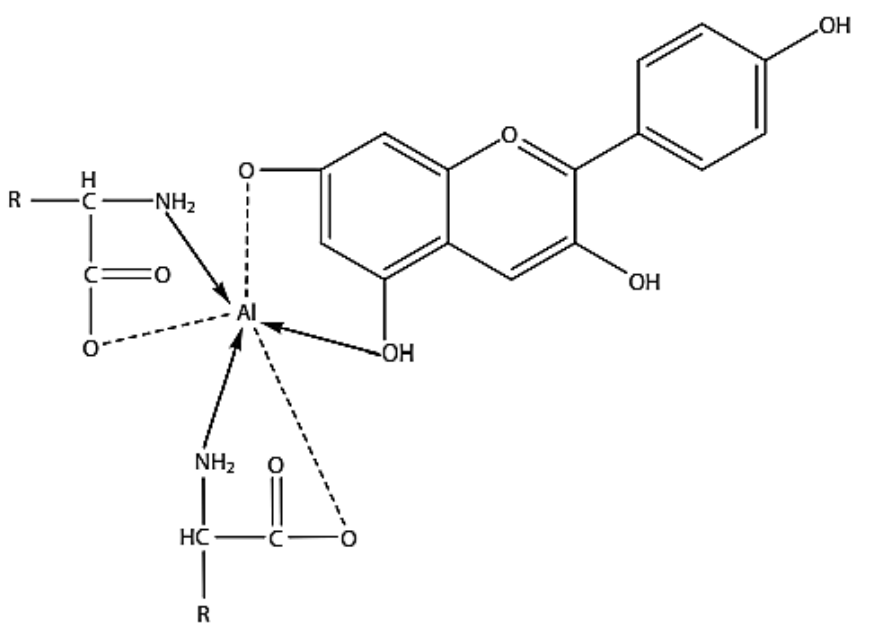

Figure 3: Complex formation among dye (pelargonidin), fabric (silk), and mordant (Al)

There are three types of mordant: 1. Metallic mordants (metal salts of aluminium, chromium, iron, copper and tin). 2. Tannins (myrobalan and sumach are commonly used in the textile industry). 3.Oil mordants (These are mainly used in dyeing turkey red colour from madder. The main function of the oil mordant is to form a complex with alum used as the main mordant, [21, 22]. There are three methods to apply mordants $[1,14]$

1. Premordanting: firstly, apply the mordant to fabric and then perceive dyeing.

2. Postmordanting: dyeing is done first and then mordanting carried out.

3. Meta-mordanting: mordanting in which dye and mordant apply together.

In table 2 frequently used conventional and new mordants are given.

Many researchers $[25,26]$ have been investigated the influence of the mordant on color shade on textile fabric. Singh and Purohit, [25] have studied properties of wool fibres dyed with natural dye extracted from the leaves of Symplocos racemosa using combination of mordants such as lemon juice + copper sulphate, lemon juice + potassium dichromate, lemon juice + ferrous sulphate and lemon juice + stannous chloride in the ratio of 3:1, 1:2 and 1:3 separately. Dyeing along with mordanting techniques which included premordanting, simultaneous mordanting and post mordanting has been carried out. Large range of shades is obtained because of varying mordant ratios and combinations. The wash, rub, light and perspiration fastness of the dyed samples have also been evaluated, giving fair to excellent fastness grades.

Arora et al. [26] investigated the intensity and shades of dyes extracted from the same plant but under different staining conditions: different $\mathrm{pH}$, different mordant and staining procedure. Cotton, wool and silk materials for testing were used. The results show that the shade of the obtained dye is a function not only of the type of the mordant but also of the dye-

Table 2: Conventional and new mordants, [23, 24].

\begin{tabular}{|c|c|c|c|}
\hline \multicolumn{2}{|c|}{ Conventional mordants } & \multicolumn{2}{|c|}{ Some newly discovered mordants } \\
\hline Name of mordant & Chemical formula & Name of mordant & Chemical formula \\
\hline $\begin{array}{l}\text { Alums } \\
\text { Ammonia alum } \\
\text { Chrome alum } \\
\text { Potash alum } \\
\text { Soda alum }\end{array}$ & $\begin{array}{l}\mathrm{Al}_{2}\left(\mathrm{NH}_{4}\right)_{2}\left(\mathrm{SO}_{4}\right)_{4} 24 \mathrm{H}_{2} \mathrm{O} \\
\mathrm{Cr}_{2} \mathrm{~K}_{2}\left(\mathrm{SO}_{4}\right)_{4} 4 \mathrm{H}_{2} \mathrm{O} \\
\mathrm{Al}_{2} \mathrm{~K}_{2}\left(\mathrm{SO}_{4}\right)_{4} 24 \mathrm{H}_{2} \mathrm{O} \\
\mathrm{Al}_{2} \mathrm{Na}_{2}\left(\mathrm{SO}_{4}\right)_{4} 24 \mathrm{H}_{2} \mathrm{O}\end{array}$ & Stannous sulfate & $\mathrm{SnSO}_{4}$ \\
\hline Potassium dichromate & $\mathrm{K}_{2} \mathrm{Cr}_{2} \mathrm{O}_{7}$ & Calcium chloride & $\mathrm{CaCl}_{2}$ \\
\hline Iron sulfate & $\mathrm{FeSO}_{4}$ & Calcium sulfate & $\mathrm{CaSO}_{4}$ \\
\hline Copper sulfate & $\mathrm{CuSO}_{4}$ & Calcium hydroxide & $\mathrm{Ca}(\mathrm{OH})_{2}$ \\
\hline Stannous chloride & $\mathrm{SnCl}_{2}$ & Magnesium sulfate & $\mathrm{MgSO}_{4}$ \\
\hline Manganese chloride & $\mathrm{MnCl}_{2}$ & Aluminium chloride & $\mathrm{AlCl}_{3}$ \\
\hline
\end{tabular}


ing technique. The most brilliant dyeing is achieved in silk, then in wool, and the weakest in cotton. The Figure 4 shows a "rainbow" of different shades of textile material dyed with the same color, ie shades of color obtained by extraction from the same plant, but with different $\mathrm{pH}$ of the bath.

\section{DYEING OF NATURAL TEXTILE MATERIALS WITH DYE EXTRACTED FROM ONION'S OUTER SHELL}

Onion's outer shell can be used as dye for dying natural textile materials. Onion's outer shell (Allium cepa) belongs to the Lilliaceae family and is grown all over the world. These dyes, which are known as pelargonidin (3, 5, 7, 4'-tetrahydroxyanthocyanidin), work like acid dyes that can dye the protein fibers at high

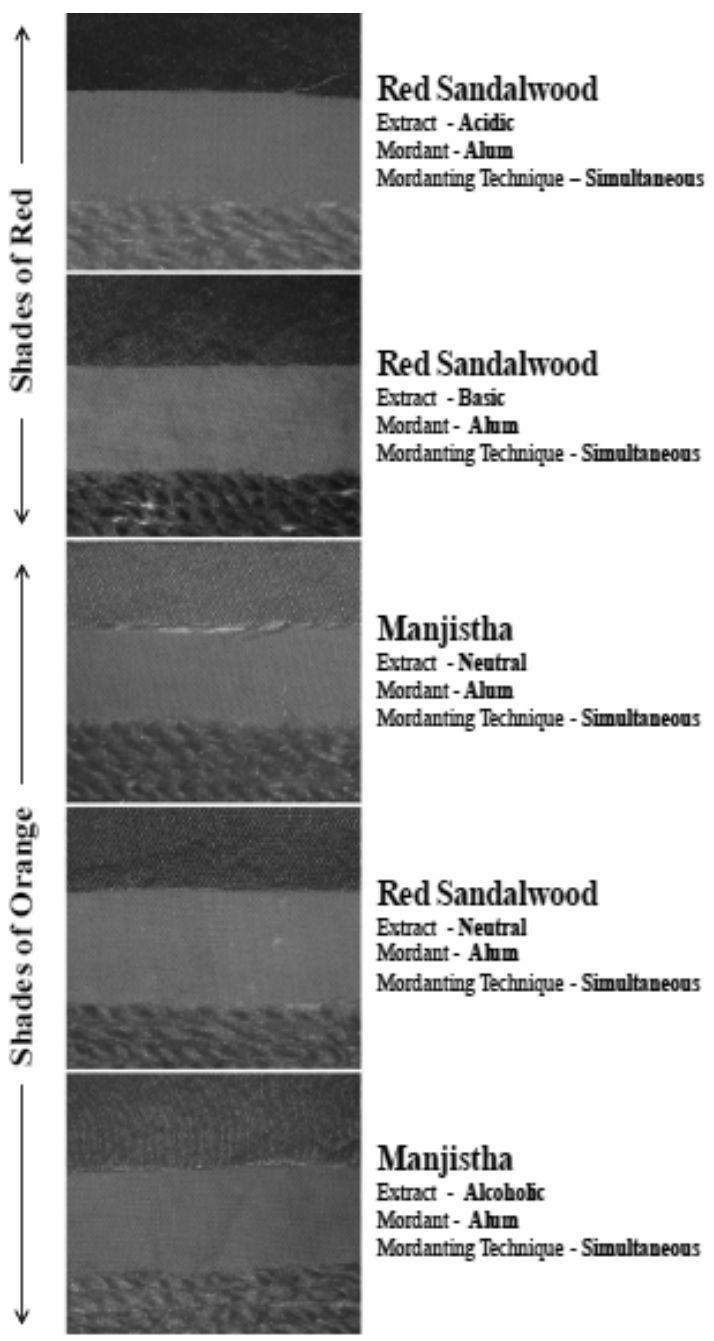

a) efficiency. The amount of pelargonidin was found to be $2.25 \%$ in certain solvent extraction process using soxhlet apparatus. Due to presence of four hydroxy groups (Auxochrome groups) pelargonidin exhibits good dyeing properties for dyeing of natural fibers. Figure 5 shows the molecular structure of onion's outer shell dye (pelargonidin) $[9,27,28]$.

Yellow onion's outer shell creates a golden range of earthy colors. Miah et al. [9] investigated the difference between two types of solvents used for onion dye extracted from onion's outer shell and effect of the three different mordants on the obtained color hue of wool fabric. Methanol extracted onion dye and water extracted onion dye were used. Three different mordants alum, potash alum and copper were used.

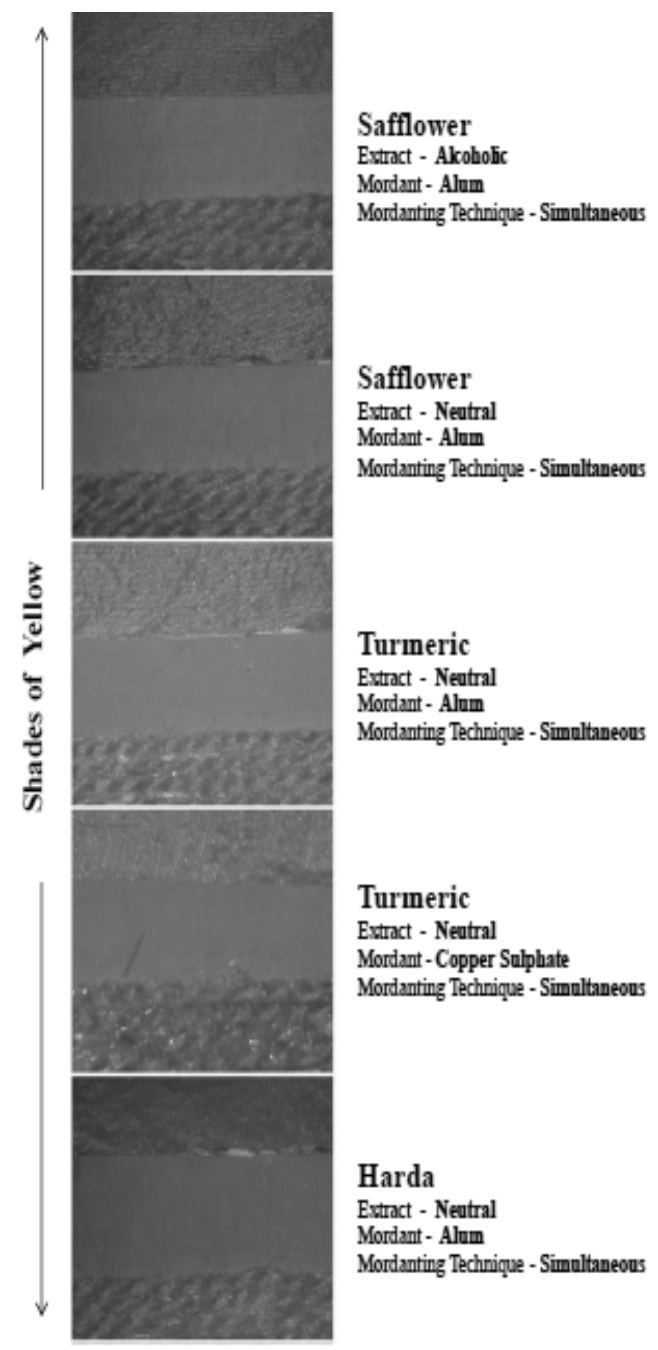

b)

Figure 4: a) Shades of orange and red produced by natural dyes on silk (top), cotton (middle) and wool (bottom) in each card. Extract type, mordant and mordanting technique used is indicated,

b) Shades of yellow produced by natural dyes on silk (top), cotton (middle) and wool (bottom) in each card. Extract type, mordant and mordanting technique used is indicated Source: Arora et al. [26]. 
<smiles>Oc1ccc(-c2[o+]c3cc(O)cc(O)c3cc2O)cc1</smiles>

Figure 5: Molecular structure of pelargodinin

Alum (Aluminum sulfate) is the most common mordant. Alum does not affect on the color hue; it is easy to obtain and it is cheap and safe for work. Potash alum which is the double sulphate of potassium and aluminum, is the widely used aluminum mordant for dyeing of textiles from natural fibers. The amount of mordant required depends on the shade to be dyed. If deeper shades are being dyed, more mordant is needed. Copper mordant is copper sulfate, also called "blue vitriol" because it is found as a light blue crystal. It is most often used to fix the brown color in wool. It is not used as much as other mordants because, it is more toxic [9, 13]. Miah M.R. et al. [9] investigated the effects of different mordants on the color obtained on wool fabric in case of methanol extracted onion dye and water extracted onion dye. Table 2 shows the results obtained from staining with onion peel obtained by methanol extraction, and Table 3 shows the results obtained from staining with onion peel obtained by aqueous extraction.

Onion dye can be successfully used for dyeing of wool to obtain a wide range of soft, pastel and light colors by using metallic mordants. The results of this research show difference in the hue of the color obtained when dyeing wool with onion peel depending on the dye extraction reagent used. Better staining results are obtained when the dye is obtained by methanol extraction, than by aqueous extraction. The hues

Table 2: Wool fabric dyed samples with methanol extracted onion dye

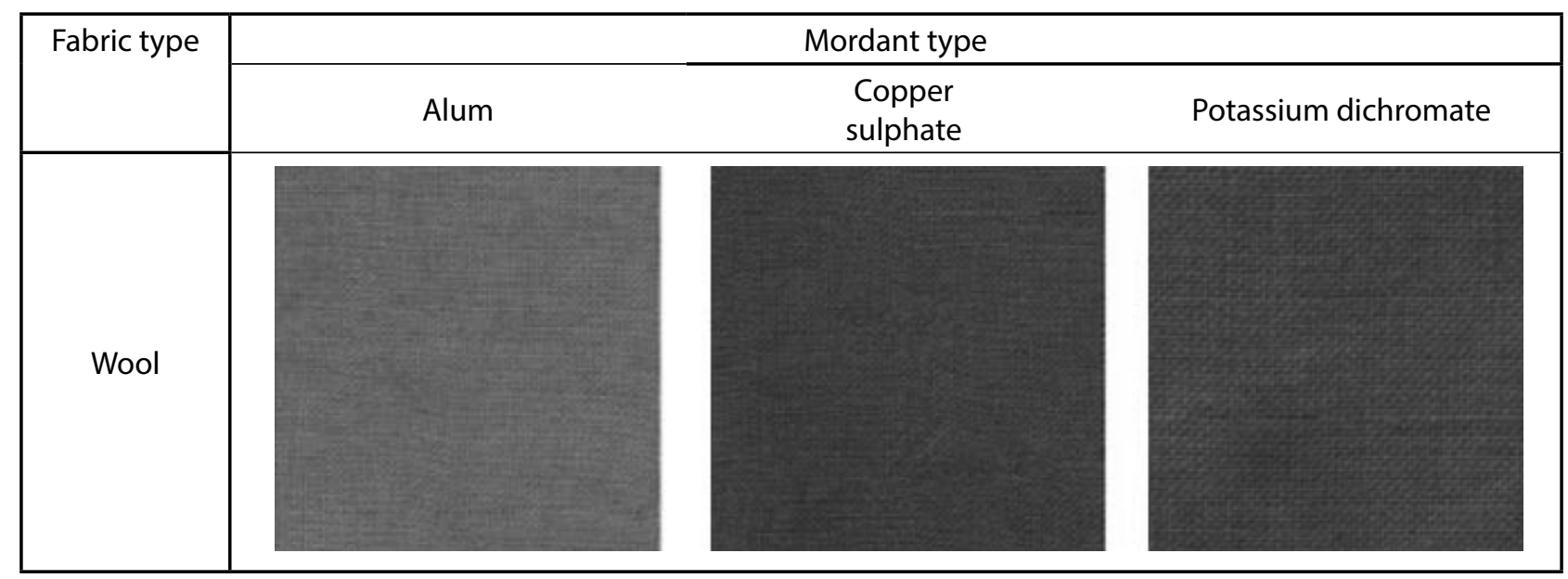

Source: Miah M.R. et al. (2016), [9].

Table 3: Wool fabric dyed samples with water extracted onion dye

\begin{tabular}{|c|ccc|}
\hline Fabric type & \multicolumn{3}{|c|}{ Mordant type } \\
\cline { 2 - 4 } & Alum & $\begin{array}{c}\text { Copper } \\
\text { sulphate }\end{array}$ & Potassium dichromate \\
\hline \multirow{2}{*}{ Wool } & & & \\
& & & \\
\hline
\end{tabular}

Source: Miah M.R. et al. (2016), [9]. 
of the color obtained by aqueous extraction are lighter, the tones are more pastel.

Very similar investigation for silk fabric was done [13]. Silk fabric is dyed with onion peel obtained by ethanol extraction and water extraction. In both cases three different mordants were used, alum, copper sulphate and potassium dichromate. Table 4 shows that potassium dichromate mordanted dyed silk fabric has deeper shade, copper sulphate mordanted and alum mordanted dyed silk fabric has medium shade (in case of ethanol extracted onion dye). Table 5 shows that potassium dichromate mordanted dyed silk fabric has deeper shade, alum mordanted dyed silk fabric medium shad and copper sulphate mordanted dyed silk fabric light shad (in case of water extracted onion dye). This research shows that the silk fabric can be easily dyed with onion's outer shell in a yellowish brown colour. In addition, the dyed samples showed a good fastness to washing.

In case of dyeing textiles from natural fibers with dye extracted from onion's outer shell, final color, its brilliance, and color fastness properties are not only dependent on the dye itself but are also determined by type of mordants [27].

Zubairu and Mshelia [29] extracted natural dye from onion's outer shell to dye cotton fabrics using selected synthetic and natural mordants. Lemon juice and Aloe vera were used as natural mordants. Cotton fabrics were dyed using each of the selected mordants under three different conventional mordanting techniques; pre-mordanting, simultaneous-mordanting and post-mordanting, adopting the well-known vat dyeing method. A wide range of soft and light colours were obtained using the various mordants considered, also the mordanting technique was found to influence the results of the dyeing process. Natural mordants gave pale yellow colours, while synthetic mordants such as copper sulphate and alum also gave yellow colours. On the other hand, iron sulphate gave darker shades of colours.

Table 4: Silk fabric dyed samples with ethanol extracted onion dye

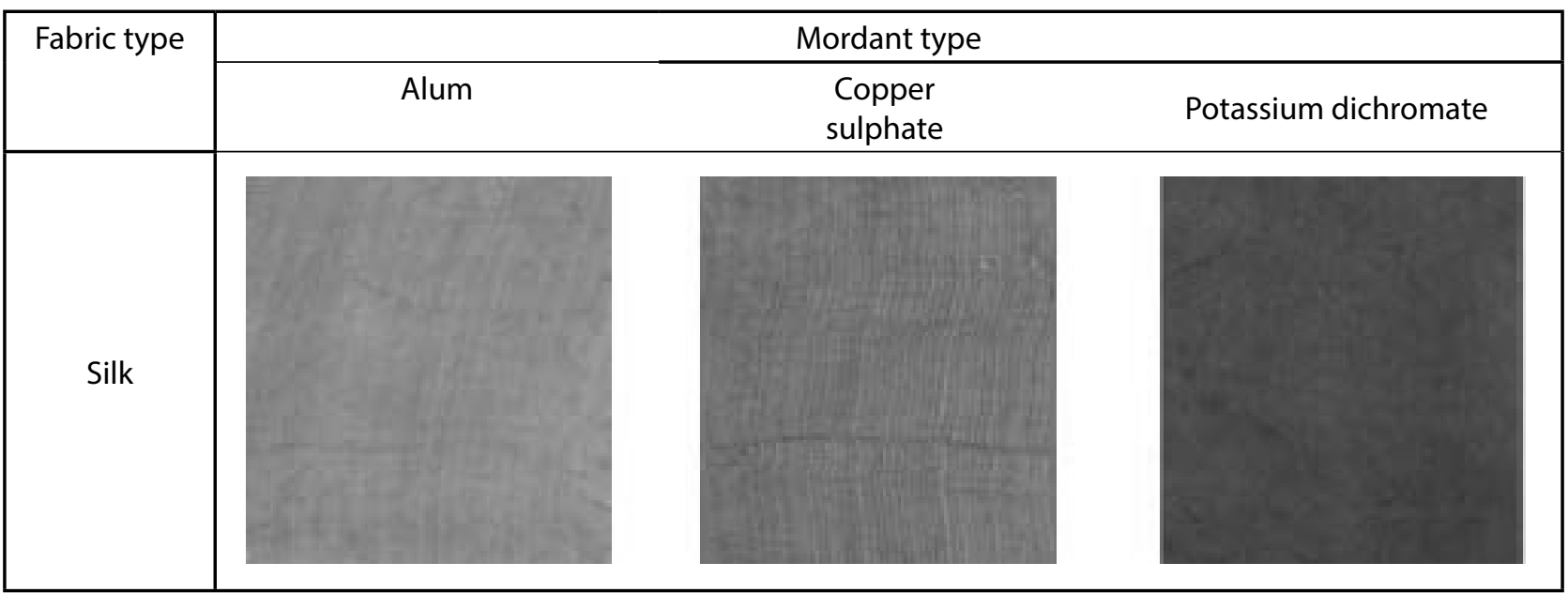

Source: Miah, M.R. et al. (2017), [13].

Table 5: Silk fabric dyed samples with water extracted onion dye

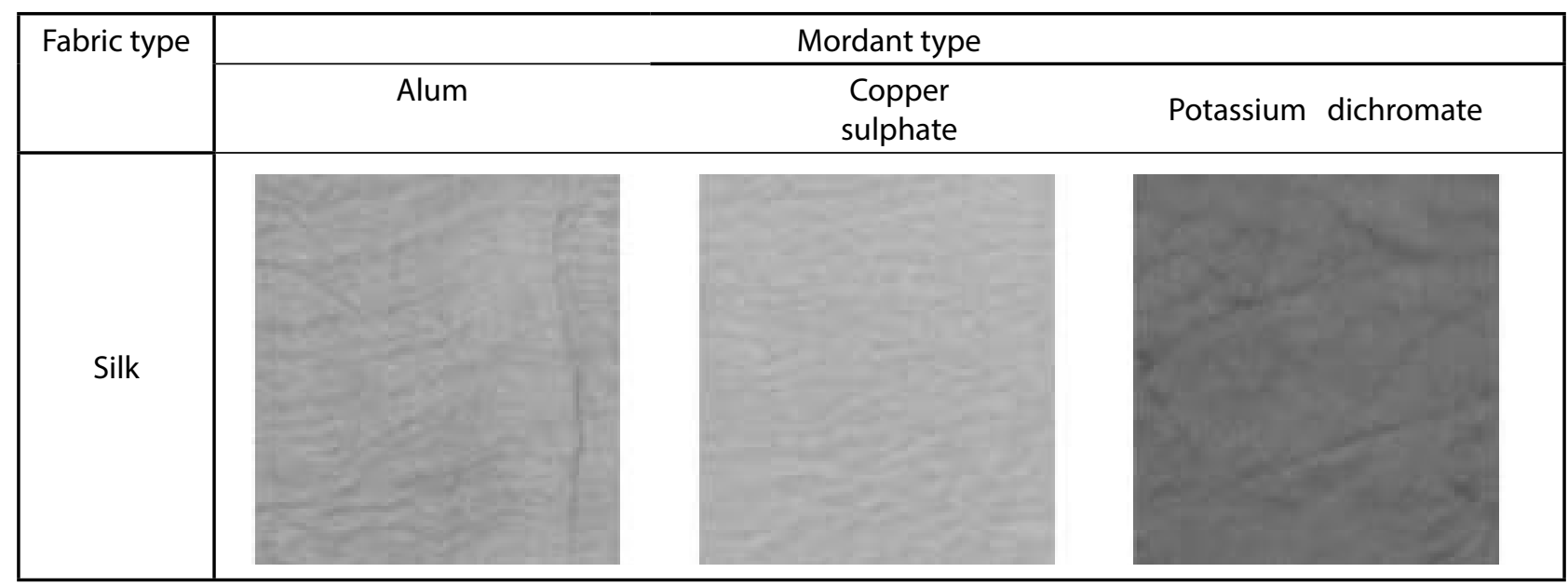

Source: Miah, M.R. et al. (2017), [13]. 


\section{CONCLUSION}

According to the experts, there is a great potential for the use of natural dyes in textile dyeing. By applying an appropriate dye extraction process and a dyeing technique, in textiles of natural origin (cotton, wool and silk) beautiful and permanent dyes are obtained. Natural dyes are ecofriendly, renewable and biodegradable and do not damage human health, but most of them need mordants to dye textiles. Some of the synthetic mordants are not eco friendly. Color of the dye on the fabric is the function not only of the mordant used, but also of the dyeing technique. Although natural dyes have several advantages, there are some limitations as well (it is difficult to reproduce shades, possibility of the change of colour influenced by the sun, sweat and air etc). The scientific studies on dyeing of textiles with natural dyes are still insufficient. There is a need for more scientific investigations in order to overcome the limitation of natural dyes.

\section{REFERENCES}

[1] Samanta, A. K., Konar, A. (2011). Dyeing of textiles with natural dyes, Institute of Jute Technology, University of Calcutta India, 30-31, 44. Available from: http://www.intechopen.com/books/natural-dyes/ dyeing-of-textiles-with-natural-dyes (Accessed: 1 October, 2020).

[2] Pubalina, S., Singhee, D., Samanta, A. K. (2018). Fundamentals of natural dyeing of textiles: Pros and Cons. Current Trends in Fashion Technology \&Textile Engineering, 2(4) ID.555593.

[3] Samanta, A.K., Agarwal, P. (2009). Application of natural dyes on textiles. Indian Journal of Fibre and Textile Research, 34, 384-399.

[4] Šmelcerović, M., Đorđević, D., Novaković, M. (2006). Bojenje tekstila bojama iz prirodnih izvora. Hem. Ind., 60(5-6), 120-128.

[5] Gupta, V. K. (2019). Fundamentals of natural dyes and its application on textile substrates. Available from https://www.intechopen.com/books/ chemistry-and-technology-of-natural-and-synthetic-dyes-and-pigments/fundamentals-of-natural-dyes-and-its-application-on-textile-substrates (Accessed: 1 October, 2020).

[6] Miah, M.R. Zakaria, Hossain, M.A., Dipto, A. I., Telegin, F. Y., Quan, H. (2016). Eco-dyeing of nylon fabric using natural dyes extracted from onion outer shells: Assessment of the effect of different mordant on color and fastness properties, Internation- al Journal of Scientific \& Engineering Research, 7(9) 1030-1043.

[7] Narendra, R., Shinyoung H., Yi Z., Yiki Y., (2013). Antimicrobial activity of cotton fabrics treated with curcumin. Journal of applied polymer science, 127(4).

[8] Šmelcerović M., Đorđević D., Mizdraković M. (2007). Ekološko oplemenjivanje vunene tkanine vodenim ekstraktima nekih biljaka. Hem. Ind., 61 (5), 251-256.

[9] Miah, M.R., Felix, Y. T., Rahman, M.S. (2016). Eco-friendly dyeing of Wool fabric using natural dye extracted from onion's outer shell by using water and organic solvents. International Research Journal of Engineering and Technology (IRJET), 3(9), 450-467.

[10] Amutha, K., Annapoorani, S.G. (2018). Eco-friendly dyeing of cotton fabric with natural dye and mordants. Asian Journal of Multidimensional Research $(A J M R), 7(2)$.

[11] Mongkholrattanasit, R., Kryštůfek, J., Wiener, J. (2010). Dyeing and fastness properties of natural dyes extracted from eucalyptus leaves using padding techniques. Fibers and Polymers 11, 346-350.

[12]Bajgot, N. S. (2017), Bojadisanje pamuka prirodnim biljnim bojilim, završni rad, Tekstilno-tehnološki fakultet, Zagreb, 17-19.

[13] Miah, M. R, Felix, Y. T., Miah, S., Shahid, A., Rahman, M.S., Ran, J. (2017). Comparative analysis of colour strength and fastness properties on extracts natural dye from onion's outer shell and its use in eco-friendly dyeing of silk fabric. International journal of photochemistry and photobiology, 2(1), 1-8.

[14] Shahid, I., (2017). Plant-based natural products, derivatives and applications, by John Wiley \& Sons, NJ 07030, USA, 20-30.

[15] Dayal, R., Dobhal, P C. (2001). Natural dyes from some Indian plants. Colourage, 48(8), 33.

[16] Teli, M. D., Paul, R. (2006). Novel natural dye from coffee seed coat. International Dyer 191(4), 29-32.

[17] Pan, N. C., Chattopadhyay, S. N., Da, A. (2003). Dyeing of jute with natural dyes. Indian Journal of Fibre \& Textile Research, 28(9), 339-342.

[18] Sarkar D, Mazumdar K, Datta S. (2006). Application of eco-friendly Floral dye on natural fibre: Flax. Man-made Text India, 49(1),19.

[19] Sarkar, D., Mazumdar, K., Datta, S., Sinha, D. K. (2006). Colouration of synthetic fibres in yellow shade using common flowers. Asian Dyer 3(3), 6164. 
[20] Tsatsaroni, E., Eleftheriadis, I. (2008). The colour and fastness of natural saffron. Coloration Technology, 110(9), 313-315.

[21] Siva, R. (2007). Status of natural dyes and dye-yielding plants in India. Current Science, 92(7), 916-925.

[22] Khan, S. A., Shahid, I., Shahid, M., Khan, M. I., Yusuf, M., Rather, L. J., Khan, M. A., Mohammad, F. (2015). Mixed metal mordant dyeing of wool using root extract of Rheum emodi (Indian Rhubarb/Dolu). Journal of Natural Fibers, 12(3), 243-255.

[23] Manian, A. P., Paul, R., Bechtold, T. (2016). Metal mordanting in dyeing with natural colourants. Coloration Technology, 132(2), 107-113.

[24] Kumaresan, M., Palanisamy, P. N., Kumar, P. E. (2012). Application of eco-friendly natural dye on cotton using combination of mordants. Indian Journal of Fibre \& Textile Research, 37(2), 194-198.

[25] Singh, S. V., Purohit, M. C. (2014). Evaluation of colour fastness properties of natural dye extracted from Symplocos racemosa (Lodh) on wool fibres using combination of natural and synthetic mordants. Indian Journal of Fibre \& Textile Research, 39(3), 97-101.
[26] Arora, J., Agarwal, P., Gupta, G. (2017). Rainbow of natural dyes on textiles using plants extracts: Sustainable and eco-friendly processes. Green and Sustainable Chemistry, 7, 35-47.

[27] Uddin, M. G. (2014). Effects of different mordants on silk fabric dyed with ion outer skin extracts. Journal of Textiles, Available from: https://www.hindawi.com/journals/jtex/2014/405626/. (Accessed: 1 November, 2020).

[28] Chandravanshi, S., Upadhyay, S. K. (2013). Interaction of natural dye (Allium cepa) with ionic surfactants. Journal of Chemistry.

Available from: https://www.hindawi.com/journals/jchem/2013/685679/ (Accessed: 9 September, 2020).

[29] Zubairu, A., Mshelia, Y. M. (2015). Effects of selected mordants on the application of natural dye from onion skin (Allium cepa). Science and Technology, 5(2), 26-32.

Rad primljen: 01.11.2020.

Rad prihvaćen: 15.11.2020. 